\title{
Trace Metal Element Analysis in Some Seafood in the Coastal Zone of the Red River (Ba Lat Estuary, Vietnam) by Green Sample Preparation and Inductively Coupled Plasma-Mass Spectrometry (ICP-MS)
}

\author{
Nhu Da Le $\mathbb{D}_{\text {, }}^{1,2}$ Thi Thu Ha Hoang,, Vu Phong Phung, 3 Thi Lien Nguyen, \\ Thi Thuy Duong $\mathbb{D},{ }^{4}$ Le Minh Dinh, ${ }^{1}$ Thi Mai Huong Pham, ${ }^{5}$ Thi Xuan Binh Phung, \\ Tien Dat Nguyen $\mathbb{D}^{7},{ }^{7}$ Thanh Nghi Duong, ${ }^{8}$ Thi My Hanh Le, ${ }^{9}$ Phuong Thu Le $\mathbb{C}^{10},{ }^{10}$ \\ and Thi Phuong Quynh Le $\mathbb{B D}^{1,2}$ \\ ${ }^{1}$ Institute of Natural Product Chemistry (INPC), Vietnam Academy of Science and Technology, 18 Hoang Quoc Viet, Cau Giay, \\ Hanoi, Vietnam \\ ${ }^{2}$ Graduate University of Science and Technology, Vietnam Academy of Science and Technology, 18 Hoang Quoc Viet, Cau Giay, \\ Hanoi, Vietnam \\ ${ }^{3}$ Institute for Technology of Radioactive and Rare Elements, 48 Lang Ha Str., Dong Da, Hanoi, Vietnam \\ ${ }^{4}$ Institute of Environmental Technology, Vietnam Academy of Science and Technology, 18 Hoang Quoc Viet, Cau Giay, \\ Hanoi, Vietnam \\ ${ }^{5}$ Hanoi University of Industry, 298 Cau Dien, Bac Tu Liem, Hanoi, Vietnam \\ ${ }^{6}$ Electric Power University, 235 Hoang Quoc Viet, Bac Tu Liem, Hanoi, Vietnam \\ ${ }^{7}$ Center for Research and Technology Transfer, Vietnam Academy of Science and Technology, 18 Hoang Quoc Viet, Cau Giay, \\ Hanoi, Vietnam \\ ${ }^{8}$ Institute of Marine Environment and Natural Resources, Vietnam Academy of Science and Technology, Hai Phong, Vietnam \\ ${ }^{9}$ Institute of Tropical Technology, Vietnam Academy of Science and Technology, 18 Hoang Quoc Viet, Cau Giay, Hanoi, Vietnam \\ ${ }^{10}$ University of Science and Technology of Hanoi, Vietnam Academy of Science and Technology, 18 Hoang Quoc Viet Road, \\ Cau Giay, Hanoi, Vietnam
}

Correspondence should be addressed to Nhu Da Le; dalenhu@gmail.com and Thi Phuong Quynh Le; quynhltp@yahoo.com

Received 14 October 2020; Revised 15 February 2021; Accepted 22 February 2021; Published 4 March 2021

Academic Editor: Tien Duc Pham

Copyright (c) 2021 Nhu Da Le et al. This is an open access article distributed under the Creative Commons Attribution License, which permits unrestricted use, distribution, and reproduction in any medium, provided the original work is properly cited.

Fisheries and aquaculture production in the coastal zone of Vietnam contribute significantly to the national economy. However, seafood quality and safety, especially in terms of metal contents, are of increasing concern, for both domestic and international markets. This paper presents the results of an investigation in some trace metal elements (iron (Fe), zinc ( $\mathrm{Zn})$, manganese (Mn), copper $(\mathrm{Cu})$, arsenic (As), cadmium $(\mathrm{Cd})$, and mercury $(\mathrm{Hg})$ ) concentrations in some fishes, crustaceans, and molluscs in the coastal zone of the Red River (in the Ba Lat estuary in Thai Binh and Nam Dinh provinces) during four sampling campaigns in 2020. All samples were treated by a green sample preparation using microwave digestion and then analyzed by inductively coupled plasma-mass spectrometry (ICP-MS). The results showed that the trace metal element concentrations in fish, crustacean, and mollusc samples decreased in the following order: $\mathrm{Fe}>\mathrm{Zn}>\mathrm{Mn}>\mathrm{Cu}>\mathrm{As}>\mathrm{Cd} \sim \mathrm{Hg}$. In more details, the ranges of trace metal elements in seafood samples were 13.13-202.73; 7.63-82.71; 0.48-22.73; 0.72-15.58; 0.18-5.12; 0.001-1.114; and $0.001-0.923 \mathrm{mg} \cdot \mathrm{kg}^{-1}$ for $\mathrm{Fe}, \mathrm{Zn}, \mathrm{Mn}, \mathrm{Cu}, \mathrm{As}, \mathrm{Cd}$, and $\mathrm{Hg}$, respectively. The research results contribute to the dataset of the seafood (both fishery and aquacultural seafood) quality in the Red River coastal zone. Although the mean values of different trace metal elements observed in this study were lower than the allowed values of Vietnam's or European's threshold for food safety, some high concentrations were detected. The survey results suggest the need to expand the monitoring scope (frequency of monitoring, number of samples, and observed variables) for obtaining a fully comprehensive assessment of seafood quality in this region. Our 
results also indicate that it is necessary to manage water quality in coastal areas, especially where aquaculture activities are carried out.

\section{Introduction}

Seafood is classified as nutritious and protein-rich foods, providing essential and trace elements $(\mathrm{Zn}, \mathrm{Fe}, \mathrm{Cu}, \ldots)$ as nutrients for human health. However, some seafood has the ability to absorb and accumulate trace metal elements in their bodies and which then affect human health when people consume seafood [1]. In parallel with the increasing demand of food safety and food consumption, trace metal element accumulation in seafood, especially in major seafood products, is particularly of great concern. Trace metal elements accumulated in different organisms are closely related to their difference in biokinetics. Wang and Guangyuan [2] review the concentrations of several major metal contaminants in bivalve molluscs collected from different regions of the world and found that oysters are the hyperaccumulators of $\mathrm{Cu}$ and $\mathrm{Zn}$, whereas scallops are the hyperaccumulator of $\mathrm{Cd}$. Thus, many species are used as environmental indicators to alert and assess water pollution. For example, oysters are usually used as a bioindicator of $\mathrm{Cu}$ and $\mathrm{Zn}$ contamination [3, 4].

Several analytical methods are used for determining trace metal element contents in seafood. Most studies use atomic absorption spectrometry (AAS) for analyzing trace metal elements in seafood, such as the determination of $\mathrm{Cr}, \mathrm{Mn}, \mathrm{Cu}$, $\mathrm{Zn}, \mathrm{As}, \mathrm{Cd}, \mathrm{Hg}$, and $\mathrm{Fe}$ in fish and crustacean samples in Bangladesh [5] or the study of $\mathrm{Cd}, \mathrm{Pb}$, and $\mathrm{Hg}$ in fish and seafood products in Bosnia and Herzegonia [6] or $\mathrm{Fe}, \mathrm{Mn}, \mathrm{Cu}$, $\mathrm{Zn}, \mathrm{Pb}, \mathrm{Ni}, \mathrm{Cd}$, and $\mathrm{Co}$ in molluscan shells in the Gulf of Aqaba and Red Sea coasts, Egypt [7]. Another method, inductively coupled plasma-mass spectrometry (ICP-MS), is also utilized for analyzing different trace metal elements in edible fish from Atlantic Coast of Muanda, Congo [8], or in shrimp and shellfish in South Korea [9]. The ICP-MS method is largely used because of its multiple advantages including the low detection limits ( 0.01 to $0.1 \mu \mathrm{g} \cdot \mathrm{L}^{-1}$ for many elements), simple specimen preparation, high throughput, and the ability to measure multielements simultaneously.

The coastal zone of the Ba Lat estuary (Red River) in Nam Dinh and Thai Binh provinces in North Vietnam is targeted to become a nationally and internationally important economic zone by the Vietnamese government. In this region, fisheries and aquaculture play an important role in the provincial economy through their role as a source of food, nutrition, income, and livelihoods for local inhabitants. Like other regions in the world, while the quantity of fisheries has increased relatively little, aquaculture in this region has been responsible for the impressive growth in the food supply for human consumption since 1995 [10].

Water and sediment quality in the coastal zone is one of the important factors that affect seafood quality in both fisheries and aquaculture sectors. Recently, some observation results of environmental quality in Thai Binh and Nam Dinh provinces showed that water and sediment environment had signs of contamination, including trace metal elements. Le Thi Lai et al. [11] reported that water channels in handicraft villages in Nam Dinh Province are loaded with trace metal elements ( $\mathrm{Zn}, \mathrm{Pb}, \mathrm{Cu}, \mathrm{Cd}, \mathrm{Cr}$, and $\mathrm{Fe}$ ), exceeding the limits by up to 50 times. Some trace metal element ( $\mathrm{Fe}, \mathrm{Zn}$, and $\mathrm{Cu}$ ) concentrations exceeded the permissible limits for coastal seawater quality QCVN 10-MT:2015/BTNMT [12, 13]. At the Ba Lat estuary, at some monitoring time, Fe concentrations in the water were from 2.2 to 9.7 times higher than the allowed value QCVN 10-MT: 2015/BTNMT [12] whereas Zn concentrations were from 1.28 to 5.12 times higher than the standard limits [14]. High contents of trace metal elements ( $\mathrm{Cu}, \mathrm{Zn}, \mathrm{Pb}, \mathrm{As}, \mathrm{Cd}$, and $\mathrm{Hg}$ ) in the coastal sediment of North Vietnam, including Thai Binh and Nam Dinh provinces, were also observed in different studies $[15,16]$. This may affect the life and quality of the fishery and aquacultural seafood in this area. Therefore, the assessment of trace metal element contents in fishery and aquacultural seafood is very important in the region. However, the study on trace metal element bioaccumulation in seafood in this region is still limited.

In the present study, we aim to apply a method basing on the digestion by microwave and the analysis by inductively coupled plasma-mass spectrometry (ICP-MS) to evaluate seven trace metal elements ( $\mathrm{Fe}, \mathrm{Zn}, \mathrm{Mn}, \mathrm{As}, \mathrm{Cu}, \mathrm{Cd}$, and $\mathrm{Hg}$ ) in three kinds of fishery and aquacultural seafood (fish, crustacean, and mollusc samples) which are widely available and major seafood products in the coastal area of the Red River in Thai Binh and Nam Dinh provinces. The research results contribute to the dataset construction of the seafood quality in this region and provide a scientific basis for the planning management for better protection and sustainable development of aquaculture in the study area.

\section{Study Site and Methodology}

2.1. Study Site. Thai Binh Province covers a surface area of $1,586 \mathrm{~km}^{2}$ with a total population of $1.8610^{6}$ inhabitants in 2019 whereas Nam Dinh Province has $1,668 \mathrm{~km}^{2}$ with $1.7810^{6}$ inhabitants [10].

Meteorological and hydrological characteristics: the climate in this region is characterized by two distinct seasons: the rainy season (from May to October) often accounts for $85-90 \%$ of the total annual rainfall (1700-1800 $\left.\mathrm{mm} \cdot \mathrm{yr}^{-1}\right)$ and the dry season (from November to next April). The monthly average air temperature ranges from 14 to $27^{\circ} \mathrm{C}$. In this region, the tidal regime is diurnal with an average tidal of 1.6 to $1.7 \mathrm{~m}$. The highest tidal is $3.31 \mathrm{~m}$, and the smallest is $0.11 \mathrm{~m}[10,17]$.

Fishery and seafood aquaculture have developed in both Thai Binh and Nam Dinh provinces. For example, Nam Dinh Province has a brackish and marine surface area of 15,200 hectares for aquaculture and a total exploited seafood fishery of about 149,639 tons in 2018. Similarly, Thai Binh Province has a marine and brackish surface area of 15,200 hectares for aquaculture (of which 3,000 ha for clams) and a total 
production of about 229,143 tons (in 2018) [10]. More than $25 \%$ of farmers living along coastal areas seek their livelihood from coastal fishery and aquaculture activities. Note that these two provinces, especially some coastal districts such as Giao Thuy, Thai Thuy, and Tien Hai, are considered as the largest areas of clam (Meretrix sp.) production in the North and Northcentral coastal region of Vietnam [18, 19]. Agriculture mainly rice culture also contributes an important proportion to the provincial economy in this region. Most farmers have been traditionally living on food crop production and animal breeding. Tourism activities are also developing in this region due to the presence of a mangrove ecosystem and a natural beach. Small and medium industrial factories or traditional production villages for food/seafood processing, gas exploitation, and crowded circulation at seaports are also present.

Along the coastal line of these two provinces, wastewater effluents originate from inland sources including domestic villages, rice fields, factories, and inland aquaculture farms. In addition, agricultural soils in this region are contaminated by several metal element (e.g., As and Cd) crust [17]. The coastal region receives also the considerable pollutant fluxes of the Red River, which discharges directly through the Ba Lat mouth [20, 21]. Hoai et al. [15] emphasized that metal contents in sediments in the coastal zone of North Vietnam have increased with time, as a consequence of the socioeconomic development in this region.

2.2. Sample Collection. A total of 35 seafood samples were collected from cultivated aquaculture farms (for mollusc samples) and natural coastal zone (fish and crustacean samples) of Nam Dinh and Thai Binh provinces: 13 different fish samples, 12 different crustacean samples, and 10 different mollusc samples (Table 1; Figure 1). The selected organisms are widely available as major seafood products in this region. The samples were collected in four sampling campaigns in 2020 in which two sampling campaigns were organized in the dry season (January and March) and another two in the rainy season (July and August) along the coastal zone of the Thai Binh and Nam Dinh provinces. Samples were collected by the Vietnam standard method TCVN 5276-90 for aquatic products, sampling and preparation of the sample. The samples collected in aquaculture coastal zone were clams (Meretrix sp.) cultured in Giao Thuy and Tien Hai districts whereas the samples in natural zone were different wild species of fishes and crustaceans which were randomly collected along the coastal zone of the Thai Binh and Nam Dinh (Table 1; Figure 1).

2.3. Sample Treatment and Analysis. Sample storage: the samples were thoroughly washed with ultrapure water and then stored in plastic bags in an ice bucket. In the laboratory, the samples were preserved at $-20^{\circ} \mathrm{C}$ before analysis.

Sample treatment: the samples were dissected and the selected dorsal muscle tissues were lyophilized for 48 hours (Cryotec). The mass of each sample before and after freeze-drying was weighed. The dried sample was then finely ground into a powder.

In order to determine the metal concentration, 0.250 to $0.500 \mathrm{~g}$ each dried sample was weighed and digested with
$1.5 \mathrm{~mL}$ of ultrapure $\mathrm{HNO}_{3} 65 \%$ (Merck, Germany) and $2 \mathrm{~mL}$ of ultrapure $\mathrm{H}_{2} \mathrm{O}_{2} 30 \%$ (Merck, Germany) in a Teflon bomb to solubilize the metal into the ionic form. The vessels were kept at room temperature for about 1 hour before heating.

A tray of a total of 12 samples was placed on a rotary table in a microwave digestion system (Q1716, Questron, USA). As compared to the open digestion methods, the biggest benefit of microwave digestion is time-saving, lower acid consumption, preventing the loss of volatile elements, and especially avoiding exposure of analyst to corrosive acid fumes. In this study, the microwave power $(800 \mathrm{~W})$ was set to be $30 \%$ for $3 \mathrm{~min}$ (step 1), then at $60 \%$ for $6 \mathrm{~min}$ (step 2), and at $30 \%$ for $1 \mathrm{~min}$ (step 3 ).

After being cooled to room temperature $\left(25^{\circ} \mathrm{C}\right)$, the content in each Teflon vessel was transferred quantitatively into $25 \mathrm{ml}$ volumetric flask, then filled up to volume with ultrapure Milli-Q water $(18 \mathrm{M} \Omega)$. The samples were filtered through $0.45 \mu \mathrm{m}$ membrane (Whatman, Merck, Germany) before the measurement.

Trace metal elements were analyzed by ICP-MS analyzer (7700x, Agilent, USA) and quantified under specific wavelength conditions with the corresponding dilutions using ultrapure Milli-Q water, in order to be into the quantification range of each compound. Standards were simultaneously analyzed with experimental samples. Instrument deviation was checked at the beginning and the end of each measured trace element. In order to determine the background values of each species during the study period, blank samples (i.e., unexposed control filters) were routinely analyzed. Then, the real concentration of each species was calculated by subtracting the blank values from the results of the chemical analysis conducted on the exposed filters. Blank and replicated sample analyses were carried out in the same way.

All glassware, Teflon vessels were decontaminated by immersion in $10 \%$ v/v $\mathrm{HNO}_{3}$ (ultrapure, Merck, Germany) for at least $24 \mathrm{~h}$ and rinsed with ultrapure Milli-Q water.

The operating conditions of ICP-MS were optimized by using a mass standard solution to obtain the ratios of oxide ions $(\mathrm{Ce}+\mathrm{O} / \mathrm{Ce})$ and doubly positive charged ions $\left(\mathrm{Ce}^{2+} / \mathrm{Ce}^{+}\right)$ at the values of about 1.0 and $2.5 \%$, respectively (Table 2 ).

The LOD and LOQ are calculated by the following equation:

$$
\begin{aligned}
& \mathrm{LOD}=\frac{3 S \cdot C_{\mathrm{STD}}}{I_{\text {std }}-I_{\text {blank }}}, \\
& \mathrm{LOQ}=\frac{10 S \cdot C_{\mathrm{STD}}}{I_{\text {std }}-I_{\text {blank }}},
\end{aligned}
$$

where 3 is a confidence factor; $S$ is the standard deviation from 10 measurements of 10 blank samples; $C_{\text {STD }}$ is the concentration of the standard sample $\left(\mu \mathrm{g} \cdot \mathrm{L}^{-1}\right) ; I_{\mathrm{STD}}$ is the raw intensity of the standard sample (cps); and $I_{\text {blank }}$ is the raw intensity of the blank sample (cps).

The limit of detection calculated by equation (1) for $\mathrm{Fe}$, $\mathrm{Zn}, \mathrm{Mn}, \mathrm{As}, \mathrm{Cu}, \mathrm{Cd}$, and $\mathrm{Hg}$ was $0.15,1.17,0.02,0.09,0.07$, 0.01 , and $0.27 \mu \mathrm{g} \cdot \mathrm{L}^{-1}$, respectively (Table 3 ).

The target analytes were not detectable in the blank. The quality control (QC) samples of $10 \mu \mathrm{g} \cdot \mathrm{L}^{-1}$ were diluted 
TABLE 1: Sampling sites and sample information.

\begin{tabular}{|c|c|c|c|c|}
\hline Types & Species & $\begin{array}{c}\text { Number of } \\
\text { samples }\end{array}$ & Date of sampling & Sample location \\
\hline \multirow{9}{*}{ Fishes (13) } & Muraenesox cinereus & 1 & Mar. 2020 & Natural coastal zone \\
\hline & Pseudapocryptes elongates & 1 & Jan. 2020 & Natural coastal zone \\
\hline & Apogon sp. & 2 & Jan. and Mar. 2020 & Natural coastal zone \\
\hline & Trichiurus lepturus & 1 & Jan. 2020 & Natural coastal zone \\
\hline & Harpadon neheureus & 1 & Jan. 2020 & Natural coastal zone \\
\hline & Megalaspis cordyla & 1 & Jan. 2020 & Natural coastal zone \\
\hline & Chelon subviridis & 1 & Jan. 2020 & Natural coastal zone \\
\hline & Gobius sp. & 4 & $\begin{array}{l}\text { Jan., Mar., Jul. and August } \\
2020\end{array}$ & Natural coastal zone \\
\hline & Rachycentron sp. & 1 & Jan. 2020 & Natural coastal zone \\
\hline \multirow{8}{*}{$\begin{array}{l}\text { Crustaceans } \\
(12)\end{array}$} & Metapenaeus sp. & 1 & Mar. 2020 & Natural coastal zone \\
\hline & Scylla sp. & 2 & Jan. and Mar 2020 & Natural coastal zone \\
\hline & Portunus sp. & 1 & Jan. 2020 & Natural coastal zone \\
\hline & Fenneropenaeus sp. & 1 & Jan. 2020 & Natural coastal zone \\
\hline & Penaeus sp. & 3 & Jan., Jul. 2020 & Natural coastal zone \\
\hline & Stomatopoda sp. & 1 & Jan., Mar. 2020 & Natural coastal zone \\
\hline & Donax sp. & 2 & Mar. and Jul. 2020 & Natural coastal zone \\
\hline & Mierspenaeopsis hardwickii & 1 & Jul. 2020 & Natural coastal zone \\
\hline \multirow{6}{*}{ Molluscs (10) } & Sepiola sp. & 1 & Jul. 2020 & Natural coastal zone \\
\hline & Loliginidae sp. & 1 & Jul. 2020 & Natural coastal zone \\
\hline & Octopus sp. & 1 & Jul. 2020 & Natural coastal zone \\
\hline & Anadara sp. & 1 & Mar. 2020 & Natural coastal zone \\
\hline & Crassostrea sp. & 1 & Jan. 2020 & Natural coastal zone \\
\hline & $\begin{array}{c}\text { Meretrix meretrix, Meretrix lyrata, } \\
\text { Meretrix sp. }\end{array}$ & 5 & $\begin{array}{l}\text { Jan., Mar., Jul., and Aug. } \\
2020\end{array}$ & $\begin{array}{l}\text { Aquaculture coastal } \\
\text { zone }\end{array}$ \\
\hline
\end{tabular}

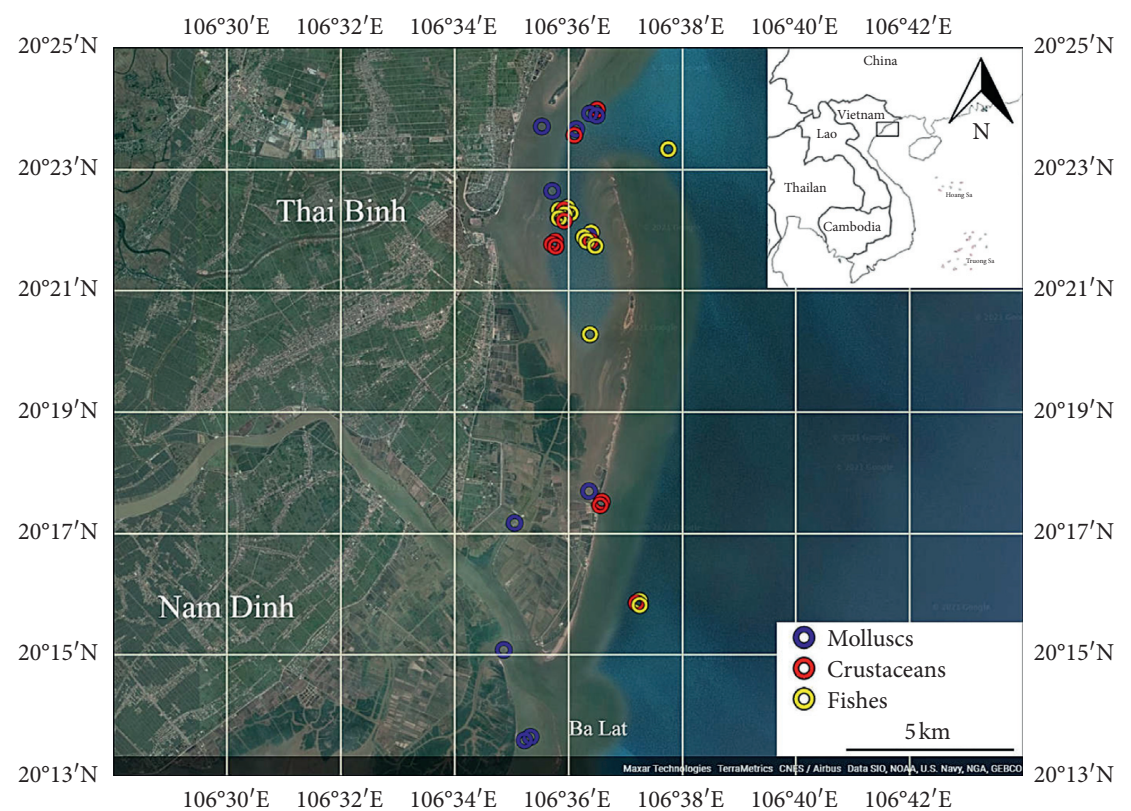

Figure 1: The Ba Lat estuary of the Red River, the coastal zone of the Thai Binh and Nam Dinh provinces.

from standard stock solution (Inorganic Venture, USA) to evaluate the stability of the ICP-MS system. The percent recovery of the quality control sample (QCS) was within 90-102\%, which was acceptable for the levels of the target analytes, according to the Manual on Policies and
Procedure [22], indicating the absence of a significant analytical bias.

All samples were measured three times. The $\%$ RSD value was below 10\% (Association of Official Analytical Chemists AOAC) was accepted. 
TABLE 2: Operating parameters of the ICP-MS system.

\begin{tabular}{lc}
\hline Parameters & Value \\
\hline RF power & $1250 \mathrm{~W}$ \\
RF matching & $1.45 \mathrm{~V}$ \\
Sample delay & $90 \mathrm{~s}$ \\
Sample uptake flow & $0.1 \mathrm{ml}^{-1} \mathrm{~min}^{-1}$ \\
Sample depth & $6.4 \mathrm{~mm}$ \\
Plasma gas & $15 \mathrm{~L} \cdot \mathrm{min}^{-1}$ \\
Carrier gas flow & $1.2 \mathrm{~L} \cdot \mathrm{min}^{-1}$ \\
Auxiliary gas flow & $0.9 \mathrm{~L} \cdot \mathrm{min}^{-1}$ \\
Pressure analytical & $3.10^{-4}-2.10^{-3} \mathrm{~Pa}$ \\
The ion lens voltage & $5.75 \mathrm{~V}$ \\
Coolant flow & $2.2 \mathrm{~L} \cdot \mathrm{min}^{-1}$ \\
Coolant temp & $2{ }^{\circ} \mathrm{C}$ \\
Data acquisition: & \\
$\quad$ Peak pattern & Full quant $(3)$ \\
$\quad$ Integrations time & $0.1 \mathrm{~s}$ \\
Repetition & 3 \\
Analytical mass & $\mathrm{Fe}(57), \mathrm{Zn} \mathrm{(66),} \mathrm{Mn} \mathrm{(55),} \mathrm{As} \mathrm{(75),} \mathrm{Cu} \mathrm{(63),} \mathrm{Cd} \mathrm{(111),} \mathrm{Hg} \mathrm{(202)}$ \\
\hline
\end{tabular}

TABle 3: LOD and LOQ values of analyzed trace metal elements by ICP-MS.

\begin{tabular}{lcccccc}
\hline Element & $S$ & Blank signals $I_{\text {blank }}$ & Standard signals $I_{\text {stand }}$ & Standards concentration $\left(\mu \mathrm{g} \cdot \mathrm{L}^{-1}\right)$ & LOD $\left(\mu \mathrm{g} \cdot \mathrm{L}^{-1}\right)$ & LOQ $\left(\mu \mathrm{g} \cdot \mathrm{L}^{-1}\right)$ \\
\hline $\mathrm{Cu}$ & 1.37 & 5.92 & 597.36 & 10 & 0.07 & 0.23 \\
$\mathrm{Cd}$ & 1.27 & 4.51 & 3963.70 & 10 & 0.01 & 0.03 \\
$\mathrm{Zn}$ & 1.70 & 6.75 & 50.35 & 10 & 0.17 \\
$\mathrm{Fe}$ & 3.79 & 255.26 & 1012.41 & 10 & 0.15 \\
$\mathrm{Mn}$ & 1.55 & 175.75 & 3359.39 & 10 & 0.50 \\
$\mathrm{As}$ & 1.42 & 2.38 & 453.91 & 10 & 0.09 \\
$\mathrm{Hg}$ & 1.43 & 4.42 & 165.33 & 10 & 0.05 \\
\hline
\end{tabular}

2.4. Statistical Analysis. To detect the correlation between seven trace metal elements of 35 observed samples, the statistical software XLSTAT [23] was used to calculate the Pearson correlation coefficients. Principal component analysis (PCA) was then used to identify representative variables for each group (fish, crustacean and mollusc samples).

Student's $t$-test was used to test the difference of variable values between two seasons (wet and dry). Probabilities $(p)$ were determined, and a $p$ value of $<0.05$ was considered to be significant.

\section{Results and Discussion}

3.1. Trace Metal Element Concentrations in Fish, Crustacean, and Mollusc Samples. Fe is an essential nutrient for many organisms, especially for humans. Fe deficiency can lead to anemia and impaired intellectual development; however, higher Fe concentrations (e.g, $60 \mathrm{mg} \cdot \mathrm{kg}^{-1}$ for one serving) can cause multiorgan failure, coma, seizures, and even death $[24,25]$. In this study, the average contents of Fe were quite high, $51.23 \pm 13.81 \mathrm{mg} \cdot \mathrm{kg}^{-1}$ for fish, $89.92 \pm 58.65 \mathrm{mg} \cdot \mathrm{kg}^{-1}$ for crustaceans, and $113.14 \pm 65.91 \mathrm{mg} \cdot \mathrm{kg}^{-1}$ for mollusc samples (Table 4, Figure 2). Note that there is no available regulation for the permissible value of Fe content in fishery seafood.

$\mathrm{Mn}$ is an essential element as an antioxidant, for blood sugar regulation and bone growth [28]; however, high Mn contents can affect human health causing a Parkinson-like syndrome [29]. The mean contents of $\mathrm{Mn}$ were $5.99 \pm 4.72 \mathrm{mg} \cdot \mathrm{kg}^{-1}$ for fish, $6.37 \pm 6.04 \mathrm{mg} \cdot \mathrm{kg}^{-1}$ for crustaceans, and $8.24 \pm 8.26 \mathrm{mg} \cdot \mathrm{kg}^{-1}$ for mollusc samples (Table 4, Figure 2). At present, no available regulation on the permissible Mn content in fishery seafood exists.

$\mathrm{Cu}$ usually exists under the form of organic complexes and is distributed in the tissues of some human organisms. However, long-time exposure to $\mathrm{Cu}$ can affect human health such as liver and kidney damage [30]. The UK Food Standards Committee suggested that $\mathrm{Cu}$ concentrations in food should not exceed a value of $10.0 \mathrm{mg} \cdot \mathrm{kg}^{-1}$ as wet weight [27]. In this study, $\mathrm{Cu}$ contents averaged $1.84 \pm 1.13 \mathrm{mg} \cdot \mathrm{kg}^{-1}$ for fish, $4.08 \pm 2.22 \mathrm{mg} \cdot \mathrm{kg}^{-1}$ for crustacean, and $5.52 \pm 4.19 \mathrm{mg} \cdot \mathrm{kg}^{-1}$ for mollusc samples (Table 4, Figure 2). The $\mathrm{Cu}$ mean value in fish samples was still far below the threshold of FAO/WHO [26]. For crustaceans, even though the maximal observed value $\left(7.22 \mathrm{mg} \cdot \mathrm{kg}^{-1}\right)$ exceeded the EU threshold (5 mg. $\mathrm{kg}^{-1}$ ) [27], the average value in crustaceans was lower than the EU threshold (Table 4). No permissible value for $\mathrm{Cu}$ in molluscs for both national and international regulations is proposed.

$\mathrm{Zn}$ is an essential micronutrient to maintain certain biological functions for animals and humans. High $\mathrm{Zn}$ concentration however can lead to the loss of appetite, growth retardation, skin changes, comatose, and immunological abnormalities [31, 32]. In this study, the mean $\mathrm{Zn}$ contents were $17.51 \pm 7.7 \mathrm{mg} \cdot \mathrm{kg}^{-1}$ for fish, $20.61 \pm 7.38 \mathrm{mg} \cdot \mathrm{kg}^{-1}$ for crustaceans, and $25.82 \pm 20.60 \mathrm{mg} \cdot \mathrm{kg}^{-1}$ for mollusc samples (Table 4, 
TABLE 4: Average (min-max) values of heavy metal contents $\left(\mathrm{mg} \cdot \mathrm{kg}^{-1}\right)$ in fish, crustacean, and mollusc samples.

\begin{tabular}{|c|c|c|c|c|c|c|c|c|}
\hline Samples & & $\mathrm{Mn}$ & $\mathrm{Fe}$ & $\mathrm{Cu}$ & $\mathrm{Zn}$ & As & $\mathrm{Cd}$ & $\mathrm{Hg}$ \\
\hline \multirow{5}{*}{ Fish } & Average & 5.99 & 51.23 & 1.84 & 17.51 & 1.10 & 0.02 & 0.19 \\
\hline & Min-max & $1.46-17.06$ & $38.02-76.54$ & $0.72-3.89$ & $7.63-31.26$ & $0.18-1.76$ & $0.001-0.076$ & $0.01-0.54$ \\
\hline & QCVN 8-2:2011/BYT & - & - & - & - & - & 0.1 & 1 \\
\hline & QĐ 46-2007 BYT & - & - & 30 & 100 & $2^{*}$ & 0.05 & 0.5 \\
\hline & FAO/WHO 1989 [26] & - & - & 30 & 40 & - & 0.5 & - \\
\hline \multirow{5}{*}{ Crustacean } & Average & 6.37 & 89.92 & 4.08 & 20.61 & 2.40 & 0.26 & 0.40 \\
\hline & Min-max & $0.78-19.90$ & $31.15-195.76$ & $1.10-7.22$ & $12.68-40.35$ & $0.87-5.12$ & $0.04-1.11$ & $0.001-0.923$ \\
\hline & QCVN 8-2:2011/BYT & - & - & - & - & - & 0.5 & 0.5 \\
\hline & QĐ 46-2007 BYT & - & - & - & - & $2.00^{*}$ & 0.5 & 0.5 \\
\hline & EU 2006 [27] & - & - & 5 & 50 & 5 & 0.5 & 0.5 \\
\hline \multirow{4}{*}{ Mollusc } & Average & 8.24 & 113.14 & 5.52 & 25.82 & 1.99 & 0.25 & 0.22 \\
\hline & Min-max & $0.48-22.73$ & $13.13-202.73$ & $2.12-15.58$ & $9.75-82.71$ & $1.06-3.32$ & $0.004-0.85$ & $0.01-0.79$ \\
\hline & QCVN 8-2:2011/BYT & - & - & - & - & & 0.5 & 0.5 \\
\hline & QĐ 46-2007 BYT & - & - & - & - & 2.00 & 0.5 & 0.5 \\
\hline
\end{tabular}

Note. ${ }^{*}$ Inorganic As concentration in seafood. Bold values indicate that they are the mean (average) values for 7 trace metal elements in three kinds of seafood.

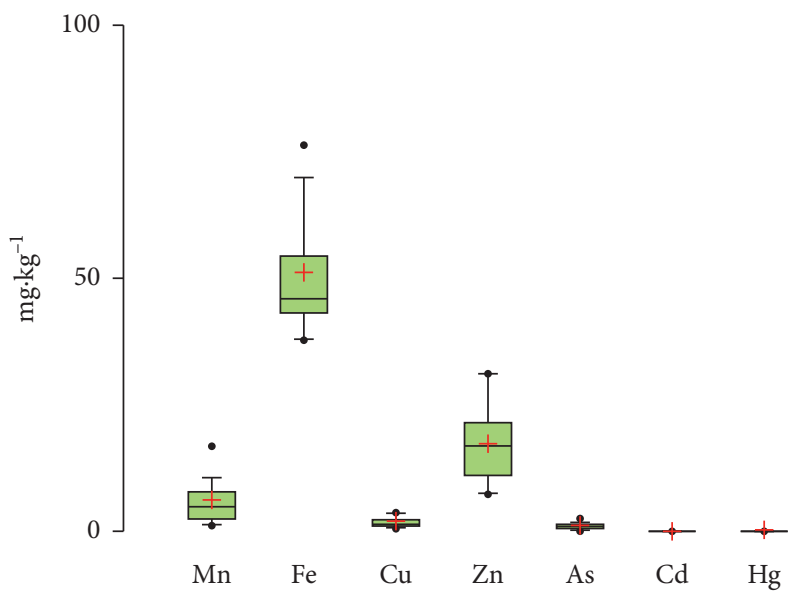

(a)

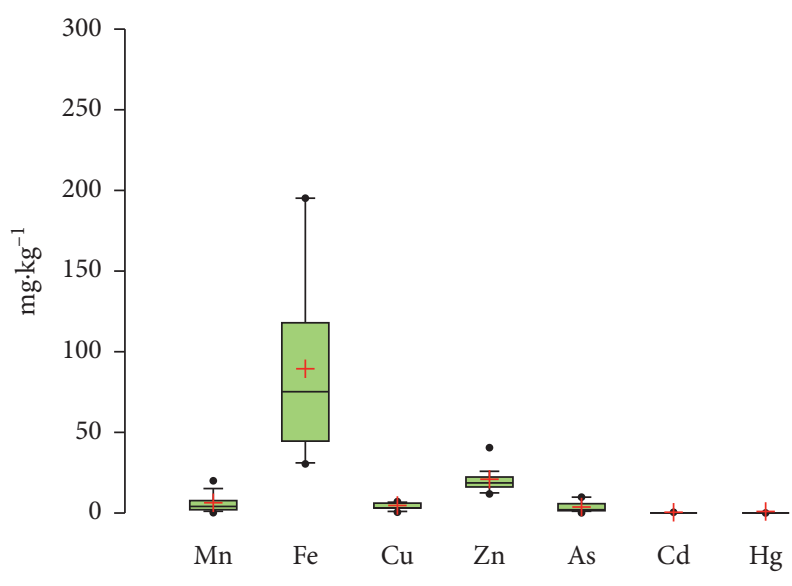

(b)

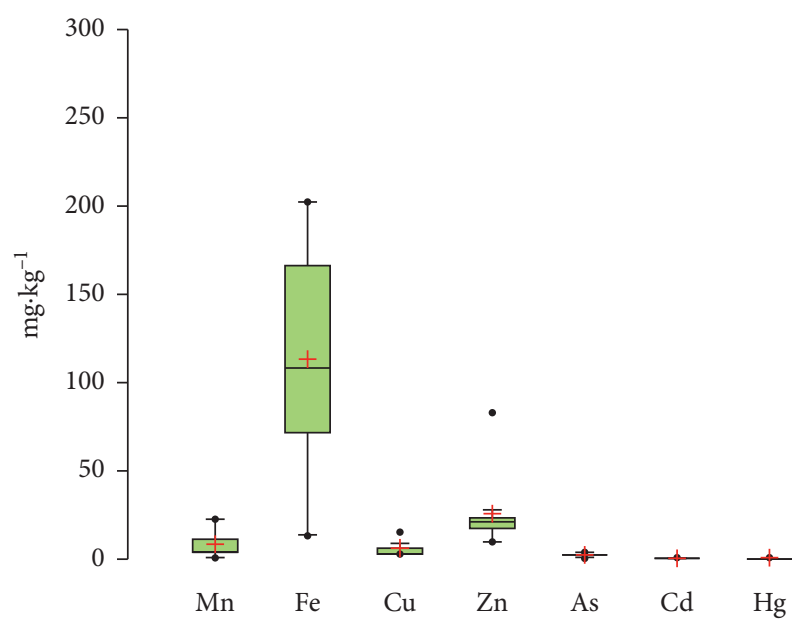

(c)

Figure 2: Trace metal element contents in (a) Fishes, (b) Crustaceans, and (c) Moluscs in the Red River coastal zone.

Figure 2). The mean value of $\mathrm{Zn}$ contents in fish in this study was below the threshold of FAO/WHO (1989) [26]. For crustacean samples, the mean $\mathrm{Zn}$ value was below the EU 2006 threshold. No permissible $\mathrm{Zn}$ content in molluscs is proposed in both national and international regulations. However, the maximal value $\left(82.71 \mathrm{mg} \cdot \mathrm{kg}^{-1}\right)$ was detected in Meretrix sp. 
Different As species may be found in food, but organic As is less toxic than inorganic As (arsenite and arsenate) for human health. There is an elevated risk of cancer and other diseases or even death if high inorganic As is present in foods consumed. Lower As exposure can cause nausea and vomiting, decreased red and white blood cell production, and abnormal heart rhythms [32]. In this study, the total As concentrations averaged $1.10 \pm 0.46 \mathrm{mg} \cdot \mathrm{kg}^{-1}$ for fish, $2.40 \pm 1.41 \mathrm{mg} \cdot \mathrm{kg}^{-1}$ for the crustacean, and $1.99 \pm 0.69 \mathrm{mg} \cdot \mathrm{kg}^{-1}$ for mollusc samples. It is worth to noting that inorganic As was not analyzed in this study; thus, the results could not be compared to the permitted value of the Vietnam Ministry of Health QD 46-2007 BYT ( $2 \mathrm{mg} \cdot \mathrm{kg}^{-1}$ for inorganic As). For crustaceans, As mean content was still lower than the Bangladesh $\left(5 \mathrm{mg} \cdot \mathrm{kg}^{-1}\right)$ [33] and the EU seafood regulations. The As contents in mollusc samples in this study were close to that reported recently for the Meretrix sp. samples (1.284-2.553 mg. $\mathrm{kg}^{-1}$ ) cultured in the Thai Binh coastal zone [13].

$\mathrm{Cd}$ is a nonessential element for most living organisms. Cd can cause kidney failure, soften bones, and even cause prostate cancer due to long-term exposure or high doses $[26,32,34]$. In this study, Cd content averaged $0.02 \pm 0.02 \mathrm{mg} \cdot \mathrm{kg}^{-1}$ for fish, $0.26 \pm 0.32 \mathrm{mg} \cdot \mathrm{kg}^{-1}$ for crustaceans, and $0.25 \pm 0.24 \mathrm{mg} \cdot \mathrm{kg}^{-1}$ for mollusc samples (Table 4, Figure 2). The mean values of $\mathrm{Cd}$ contents in fish were below the threshold specified by the Vietnamese regulations of QCVN 8-2: 2011/BYT and QD 46-2007 BYT and by the FAO/ WHO 1989 [26] or the European Community legislation [34] (Table 4). For crustaceans, note that the Cd content in the Stomatopoda sp. sample $\left(1.11 \mathrm{mg} \cdot \mathrm{kg}^{-1}\right)$ was two folds higher than the Vietnamese threshold; however, the mean Cd value of all observed crustacean samples was below the threshold specified by the QCVN 8-2: 2011/BYT and QD 46-2007 BYT as well as the EU 2006 and by Bangladesh $\left(0.5 \mathrm{mg} \cdot \mathrm{kg}^{-1}\right)$ [33].

$\mathrm{Hg}$ is a toxic element due to its strong affinity with the sulphur atom in the enzyme protein structure of living organisms. High $\mathrm{Hg}$ accumulation in human organisms can cause kidney failures, memory loss, numbness, physical tremors and neurological dysfunction, or other diseases (e.g., Minamata) [13]. In this study, $\mathrm{Hg}$ content averaged $0.19 \pm 0.17 \mathrm{mg} \cdot \mathrm{kg}^{-1}$ for fish, $0.40 \pm 0.26 \mathrm{mg} \cdot \mathrm{kg}^{-1}$ for crustaceans, and $0.22 \pm 0.31 \mathrm{mg} \cdot \mathrm{kg}^{-1}$ for mollusc samples. The mean $\mathrm{Hg}$ values in the fish, crustacean, and mollusc samples were lower than the threshold specified by the Vietnamese regulations of QCVN 8-2: 2011/BYT and QD 46-2007 BYT as well as other regulations (the EU 2006; Bangladesh's one) (Table 4). The Hg contents in mollusc samples in this study were close to those recently reported for the Meretrix sp. samples $\left(0.045-0.472 \mathrm{mg} \cdot \mathrm{kg}^{-1}\right.$, average of $\left.0.248 \mathrm{mg} \cdot \mathrm{kg}^{-1}\right)$ cultured in the Thai Binh coastal zone [13].

Our observation results showed that the trace metal element concentrations in fish, crustacean, and mollusc samples were in decreasing order: $\mathrm{Fe}>\mathrm{Zn}>\mathrm{Mn}>\mathrm{Cu}>\mathrm{As}>\mathrm{Hg} \sim \mathrm{Cd}$. For all samples observed, the mean values of Fe contents were always the highest, and $\mathrm{Cd}$ and $\mathrm{Hg}$ contents were the lowest.

\subsection{Relationship between Trace Metal Element Accumulation in Fishery and Aquaculture Seafood}

3.2.1. Pearson and PCA Analysis. The results of the Pearson correlation coefficients for 7 trace metal elements of 35 observed samples showed that the significant relationship was found between $\mathrm{Mn}-\mathrm{Fe}$; $\mathrm{Cu}-\mathrm{Zn}$; $\mathrm{Cd}-\mathrm{As}$; and $\mathrm{Hg}-\mathrm{Cd}$ (Table 5).

Relation between trace metal elements and biological groups is shown using PCA (Figure 3). The first two axes account for $55.5 \%$ of the variance, and the three conditions are clearly individualized: high level of $\mathrm{Hg}$, As, and $\mathrm{Cd}$ accumulated in crustaceans samples is located in the right lower quarter; high level of $\mathrm{Mn}, \mathrm{Zn}, \mathrm{Cu}$, and Fe accumulated in mollusc samples is located in the right superior quarter, and low metal accumulated in fish is located in the left quarter.

Organisms living in the aquatic environment are more likely to be exposed to trace metal elements, especially for benthic species. Crustaceans and molluscs are known to ingest or filter sediment; thus, metal accumulation in their bodies could be high [35]. Many studies have shown the high correlation between trace metal contents in sediment and in benthic organisms. Nour [7] studied on the contents of Fe, $\mathrm{Mn}, \mathrm{Cu}, \mathrm{Zn}, \mathrm{Pb}, \mathrm{Ni}, \mathrm{Cd}$, and $\mathrm{Co}$ in molluscan shells and associated surface sediments on the Gulf of Aqaba and Red Sea coasts, Egypt, and found that metal bioaccumulation of molluscan species was consistent with the enrichment factors for sediments. In another study, significant correlation of $\mathrm{Cd}, \mathrm{Cu}, \mathrm{Pb}$, and $\mathrm{Zn}$ in sediments and oysters (Saccostrea cucullata) collected from Qeshm Island, Persian Gulf, Iran, was also demonstrated [36]. The authors revealed the soft tissues of $S$. cucullata as a more accurate biomonitoring organism for $\mathrm{Cu}, \mathrm{Pb}$, and $\mathrm{Cd}$ in sediments in this region [36]. Our results also showed that higher trace metal element contents in both crustaceans and molluscs in benthic sediment than in pelagic fishes $(p<0.05)$ were observed in the coastal zone of the Red River (Table 4, Figure 2). Moreover, in our study, some higher contents of trace metal elements $(\mathrm{Cu}, \mathrm{Cd}$, and $\mathrm{Hg}$ ) than the allowed values for seafood safety were found for several crustaceans and mollusc samples, including Meretrix sp. High contents of trace metal elements ( $\mathrm{Cd}$ and $\mathrm{Hg}$ ) in Meretrix sp. in some estuaries of the central Vietnam have also been previously reported [37]. This indicates that the characteristic of filter feeding was one of the factors influencing higher accumulation rates and underlines why molluscs are widely used for water biomonitoring in coastal regions.

\subsection{Factors Impacting on Trace Metal Element Accumulation} in Fishery and Aquaculture Seafood. Gammal et al. [38] revealed that the mean contents of metals in crustaceans (shrimp and crab) were relatively higher than that in sediments, which may be related to some factors such as environmental 
TABLE 5: Correlation between seven trace metal elements of 35 observed samples.

\begin{tabular}{|c|c|c|c|c|c|c|c|}
\hline & $\mathrm{Mn}$ & $\mathrm{Fe}$ & $\mathrm{Cu}$ & $\mathrm{Zn}$ & As & $\mathrm{Cd}$ & $\overline{\mathrm{Hg}}$ \\
\hline $\mathrm{Mn}$ & 1 & & & & & & \\
\hline $\mathrm{Fe}$ & $0.638^{* *}$ & 1 & & & & & \\
\hline $\mathrm{Cu}$ & -0.017 & 0.208 & 1 & & & & \\
\hline $\mathrm{Zn}$ & 0.021 & 0.113 & $0.596^{* *}$ & 1 & & & \\
\hline As & -0.131 & 0.256 & -0.105 & 0.159 & 1 & & \\
\hline $\mathrm{Cd}$ & 0.043 & $0.368^{*}$ & 0.074 & $0.404^{*}$ & $0.639^{* *}$ & 1 & \\
\hline $\mathrm{Hg}$ & -0.043 & 0.064 & -0.093 & 0.003 & 0.203 & $0.498^{* *}$ & 1 \\
\hline
\end{tabular}

Note. Values in bold letters show significant correlations * Correlation is significant at the 0.05 level (2-tailed) ${ }^{* *}$ Correlation is significant at the 0.01 level $(2$ tailed).

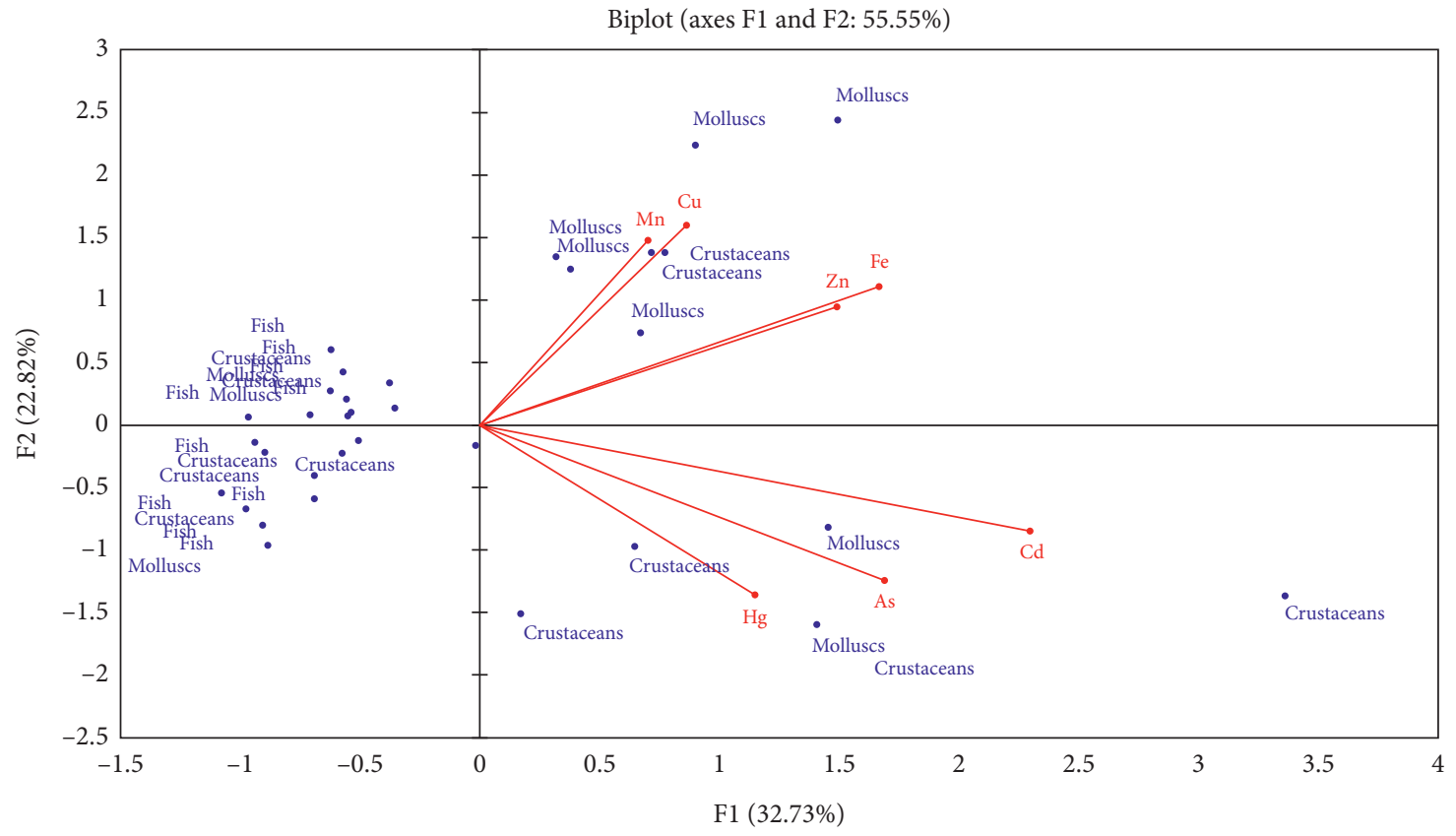

- Active variables

- Active observations

Figure 3: PCA analysis of 7 trace metal elements in 35 observed samples in the coastal zone of the Red River in Thai Binh and Nam Dinh provinces in 2020 .

quality, feeding strategies, metabolic activities, or dietary uptake of habitat. In comparison to other work, most trace metal element contents in seafood in the Red River coastal zone were much lower than that in Isobbe, Limbe, Cameroon [39], but far higher than that in Arabian Gulf, Saudi Arabia [38]. However, they were in the range as those from the North East Coast of India [40] or in Alexandria region, Egypt [41] (Table 6).

Previous studies also revealed that some trace metal element contents in coastal waters and sediments in this region were higher than in other coastal regions of Vietnam $[12,13,21]$. Duong et al. [21] reported that some trace metal elements $(\mathrm{Cu}, \mathrm{Hg}$, and $\mathrm{Cd})$ in both water and sediment at $\mathrm{Ba}$ Lat site during the period from 2016 to 2019 were about 2-3 folds higher than at other sites along the coastal zone in North Vietnam, even though the mean values of all observed trace metal elements were lower than the allowed values defined by the Vietnamese regulations. Other studies demonstrated the high level of some trace metal elements, e.g., Fe and Zn, in the coastal water of the Red River in Thai Binh and Nam Dinh provinces [12-14]. Moreover, Hoai et al. [15] reported that the contents of some trace metal elements $\left(\mathrm{mg} \cdot \mathrm{kg}^{-1}\right)$ in tidal flat sediment in the North Vietnam coast were as follows: $\mathrm{Cu}$, 0.69-94.76 (mean: 40.50); Pb, 5.78-120.32 (mean: 52.08); $\mathrm{Zn}$, 3.95-492.01 (mean: 85.31); As, 0.26-53.93 (mean: 18.73); Cd, 0.02-2.56 (mean: 0.44). These authors emphasized the high contents of some trace metal elements $(\mathrm{Cu}, \mathrm{Pb}, \mathrm{As}$, and $\mathrm{Cd})$, from moderately to strongly polluted environments in the $\mathrm{Ba}$ Lat water coastal zone and noted that the contamination increased with time. The higher trace metal element concentrations in both water and sediment may affect the bioaccumulation of the elements by benthic species in this region.

The difference in trace metal element contents in seafood may reflect the water and sediment quality which 


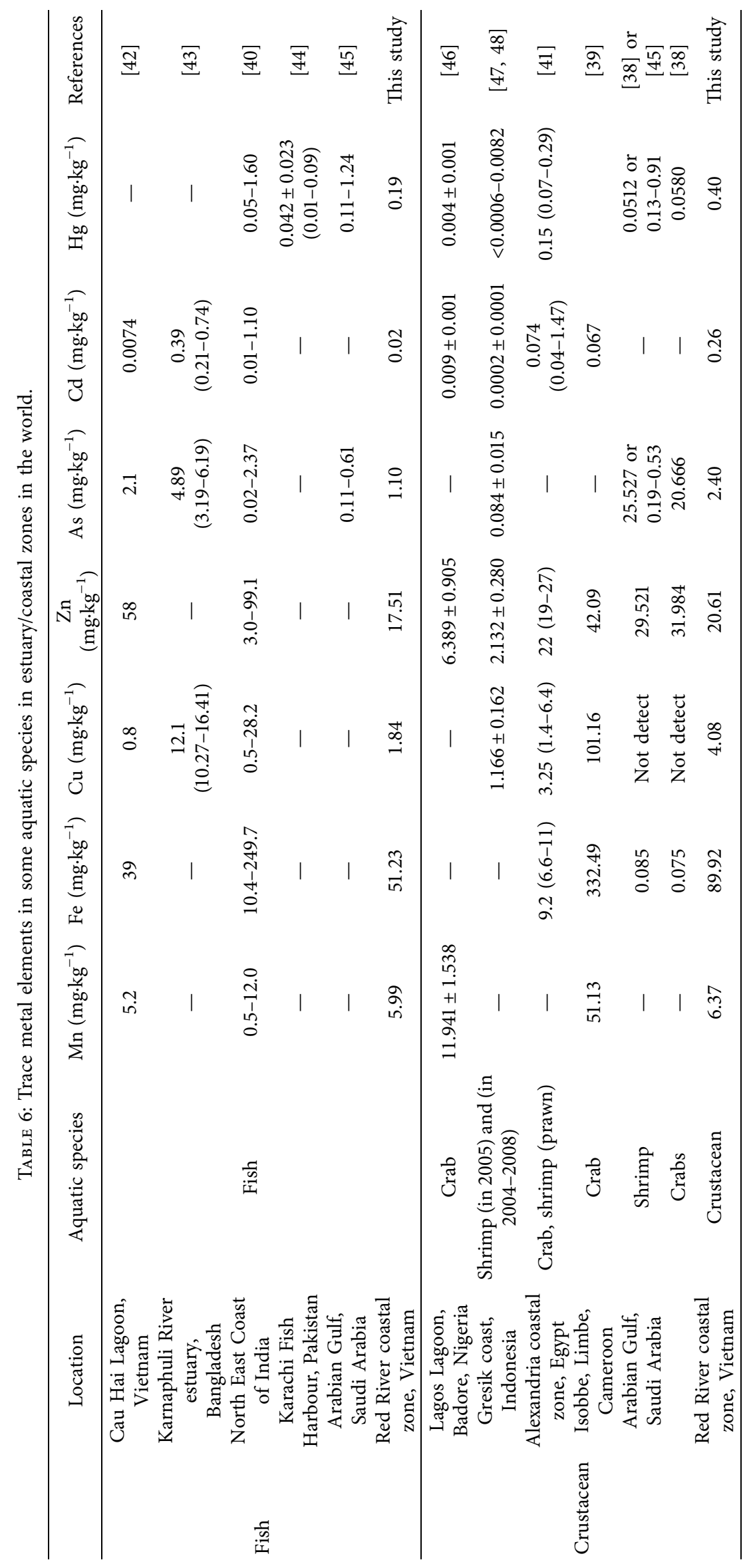




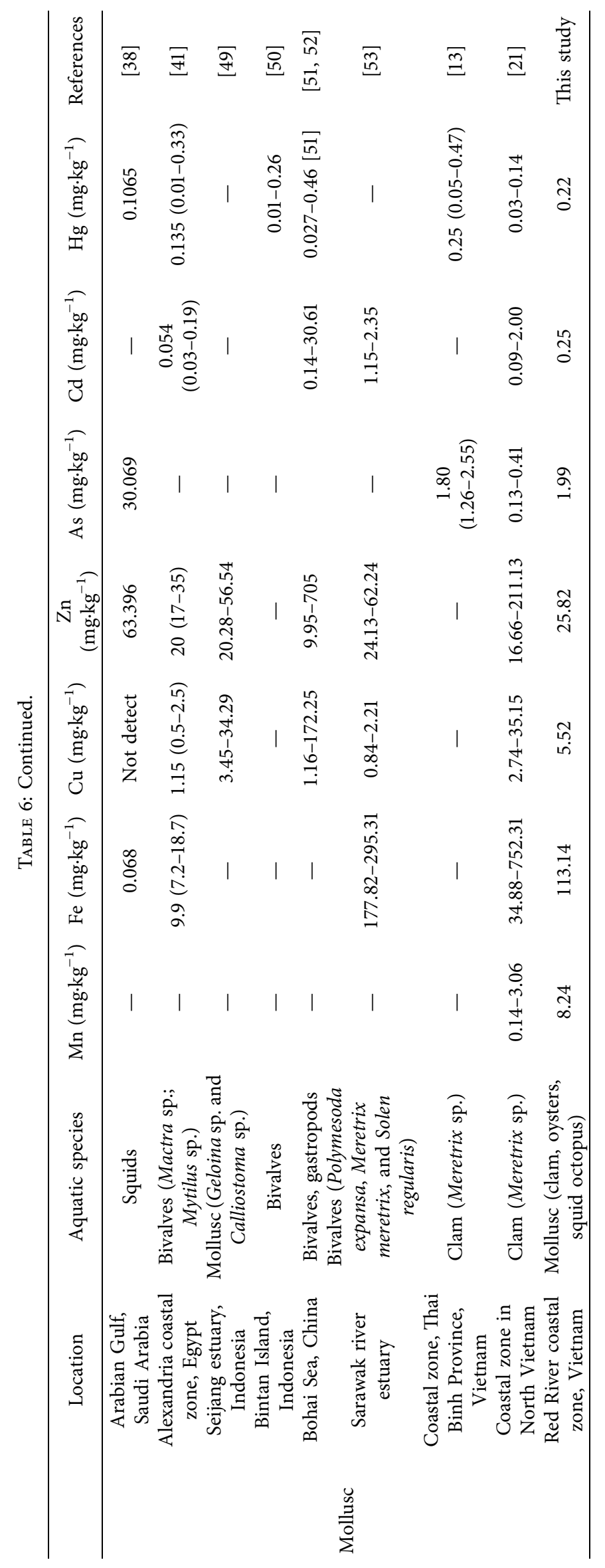


are impacted by both point and dispersal wastes sources. In our case, the pollution in the coastal water and sediment of the Thai Binh and Nam Dinh provinces probably comes from inland (domestic, agricultural, and industrial wastewater) [12, 15, 18]. Nguyen et al. [17] studied on trace metal element concentration in surface soil samples collected from different land use types in agricultural land in Nam Dinh Province and found that Cr mainly originated from a natural source. $\mathrm{Cd}$ and As have a significant anthropogenic input whereas $\mathrm{Cd}, \mathrm{Pb}$, and $\mathrm{Zn}$ have a mixed source. These authors suggested that $\mathrm{Cd}$ and As contamination in agricultural soil was possibly caused by sewage sludge, industrial wastewater, and/or residues of fertilizers and pesticides application. Phan [54] revealed the $\mathrm{Cu}$ contamination in soils of the industrial, agricultural zones, and craft villages in Thai Binh Province. Some authors $[13,16]$ reported high ranges in $\mathrm{Hg}$ content (from 0.12 to $3.79 \mathrm{mg} \cdot \mathrm{kg}^{-1}$, averaging $0.98 \mathrm{mg} \cdot \mathrm{kg}^{-1}$ ) in the surface sediment of the Red River coastal zone, probably due to the misuse of a remarkable amount of mercurial fungicides in large aquaculture production in Thai Binh Province. In addition, Nguyen et al. [55] reported that high As and trace metal element contents were observed in river sediment and in the upper soil layers of the mangrove forest soil of the Red River estuary which may reflect the intensive human activities in the upstream Red River in recent decades. Besides, Le Thi Lai et al. [11] reported that water channels in handicraft villages in Nam Dinh Province are loaded with trace metal elements (Zn, $\mathrm{Pb}, \mathrm{Cu}, \mathrm{Cd}, \mathrm{Cr}$, and $\mathrm{Fe}$ ), exceeding the limits by up to 50 times. Thus, pollution sources need to be managed to ensure fishery and aquacultural seafood quality and safety, as well as for providing better environmental quality for the sustainable development of aquaculture in the Red River coastal zone.

In the Vietnam National technical regulation on the limits of heavy metal contamination in food (QCVN 8-2: 2011/BYT), the allowed values of some trace metal elements such as arsenic, lead, cadmium, Mercury, and tin in seafood have been set. However, there is no regulation for other metals such as copper, manganese, zinc, and iron. The effects of these metals on human health have been shown in some studies [56-58]. However, risk assessments to human health of trace metal element accumulation in seafood in Vietnam are still limited. Thus, our results suggest that further studies of the risk assessment of trace metal elements in this study area and in all provinces of Vietnam are needed.

Our results on trace metal elements in fishery and aquaculture seafood are close to those reported in previous studies from the coastal zone in Vietnam such as in Cau Hai Lagoon [42], in Thai Binh Province [13], or in the North [21]. Similar levels of trace metal element contents in seafood in North Vietnam's coastal zone by using the green sample preparation and modern analytical equipment ICP-MS in this study and by other research methods (e.g., AAS analysis) was found. The ICP-MS method is more sensitive (detection at ppb levels) and can analyze multiple elements simultaneously as compared to the AAS analysis method which is cheaper but can only determine the concentration of a particular element. Moreover, our method using green sample preparation has its advantages for sample treatment as demonstrated above (Section 2.3). Thus, the method using the green sample preparation and an ICP-MS in this study should be applied for similar studies.

3.4. Limitation of This Study. Our study was conducted on limited variables (seven trace metal elements: $\mathrm{Fe}, \mathrm{Zn}, \mathrm{Mn}$, $\mathrm{As}, \mathrm{Cu}, \mathrm{Cd}$, and $\mathrm{Hg}$ ) and sample size (number of samples); thus, these results of trace metal elements in seafood of the Red River coastal zone should be interpreted as preliminary. Besides, environmental (water and sediment) quality which may explain the accumulation of trace metal elements was not observed directly in this research. Thus, further investigation about the environmental and seafood quality should be undertaken for this region. In addition, our study only focused on total trace metal element contents which may not provide enough information about the biological activity and eco-toxicity; thus, further studies concerning a separate analysis of organic and inorganic forms of observed trace metal elements or the assessment of the potential risk of adverse health effects from a mixture of toxic metals are needed.

\section{Conclusions}

Using the green sample preparation and inductively coupled plasma-mass spectrometry (ICP-MS), different trace metal element ( $\mathrm{Fe}, \mathrm{Zn}, \mathrm{Mn}, \mathrm{As}, \mathrm{Cu}, \mathrm{Cd}$, and $\mathrm{Hg}$ ) contents in 35 samples (fish, crustacean and mollusc) in the coastal zone of the Red River in the Thai Binh and Nam Dinh provinces in four sampling campaigns in 2020 were analyzed. The results showed that the trace metal element contents in fish, crustacean, and mollusc samples were in the decreasing order: $\mathrm{Fe}>\mathrm{Zn}>\mathrm{Mn}>\mathrm{Cu}>\mathrm{As}>\mathrm{Hg} \sim \mathrm{Cd}$. In more details, the trace metal element contents $\left(\mathrm{mg} \cdot \mathrm{kg}^{-1}\right)$ in all 35 samples varied from 0.48 to 22.73 for $\mathrm{Mn} ; 13.13$ to 202.73 for Fe; 0.72 to 15.58 for $\mathrm{Cu} ; 7.63$ to 82.71 for $\mathrm{Zn}$; 0.18 to 5.12 for As; 0.001 to 1.114 for Cd; and 0.001 to 0.923 for Hg. Concentrations in fish samples were lower than in crustaceans and mollusc, showing the importance of sediment sources in providing heavy metal bioaccumulation in benthic organisms (crustaceans and mollusc).

Our research results provide a dataset for both fishery and aquacultural seafood qualities in the Red River coastal zone in Nam Dinh and Thai Binh provinces. Although the mean values of the different trace metal elements observed in this study were lower than the allowed values of Vietnam or the European threshold for seafood safety, some high concentrations were detected. Thus, the expansion of monitoring scope (increasing frequencies of sampling campaigns, numbers of samples, and numbers of variables of food quality) is required for obtaining a fully comprehensive assessment of seafood quality in this region. Our study only focused on total trace metal element contents which may not always provide enough information about 
biological activity and eco-toxicity. Thus, a separate analysis of organic and inorganic forms of observed trace metal elements is needed for accurately assessing the risks of toxic metals in seafood. In addition, our results also indicate the need for managing water and sediment quality in coastal areas, especially where aquaculture activities are carried out.

\section{Data Availability}

All the data and supporting materials are included within the article.

\section{Conflicts of Interest}

The authors declare that they have no conflicts of interest.

\section{Acknowledgments}

The authors thank the financial supports of Vietnam's National Foundation for Science and Technology Development (NAFOSTED-Vietnam) for project no. 105.082019.11 (Le Nhu Da). The authors would like to thank Dr. Emma Rochelle-Newall for significant improvement of the manuscript.

\section{References}

[1] V. K. Nguyen and V. H. Pham, "Study on accumulation of heavy metals cadmium $(\mathrm{Cd})$ and lead $(\mathrm{Pb})$ in clam Corbicula sp. from estuaries, Da Nang city," Journal of Science and Technology (Da Nang University), vol. 1, no. 30, pp. 83-89, 2009.

[2] W.-X. Wang and G. Lu, "Chapter 21-heavy metals in bivalve mollusks," in Chemical Contaminants and Residues in Food, D. Schrenk and A. Cartus, Eds., pp. 553-594, Woodhead Publishing, Cambridge, UK, Second Edition, 2017.

[3] L. García-Rico, R. E. R. Ruiz, and J. V. Jiménez, "Determination of total metals in cultivated oysters (Crassostrea gigas) from the Northwest coast of Mexico by microwave digestion and atomic absorption spectrometry," Journal of AOAC International, vol. 84, no. 6, pp. 1909-1913, 2001.

[4] L. García-Rico, L. Tejeda-Valenzuela, and A. Burgos-Hernández, "Seasonal variations in the concentrations of metals in Crassostrea corteziensis from Sonora, México," Bulletin of Environmental Contamination and Toxicology, vol. 85, no. 2, pp. 209-213, 2010.

[5] M. A. Baki, M. M. Hossain, J. Akter et al., "Concentration of heavy metals in seafood (fishes, shrimp, lobster and crabs) and human health assessment in Saint Martin Island, Bangladesh," Ecotoxicology and Environmental Safety, vol. 159, pp. 153-163, 2018.

[6] J. Djedjibegovic, A. Marjanovic, D. Tahirovic et al., "Heavy metals in commercial fish and seafood products and risk assessment in adult population in Bosnia and Herzegovina," Scientific Reports, vol. 10, no. 1, p. 13238, 2020.

[7] H. E. S. Nour, "Distribution and accumulation ability of heavy metals in bivalve shells and associated sediment from Red Sea coast, Egypt," Environmental Monitoring and Assessment, vol. 192, no. 6, p. 353, 2020.

[8] R. B. Suami, P. Sivalingam, C. D. Kabala et al., "Concentration of heavy metals in edible fishes from Atlantic coast of Muanda, Democratic Republic of the Congo," Journal of Food Composition and Analysis, vol. 73, pp. 1-9, 2018.
[9] G. Habte, J. Y. Choi, E. Y. Nho et al., "Determination of toxic heavy metal levels in commonly consumed species of shrimp and shellfish using ICP-MS/OES," Food Science and Biotechnology, vol. 24, no. 1, pp. 373-378, 2015.

[10] GSO (General statistics office of Vietnam), "General Statistics Office of Vietnam,” 2020, https://gso.gov.vn/in.

[11] J. K. Le Thi Lai, D. Huy Quy, T. T. Hue, and M.-T. Schafmeister, "Geochemical characterization pathways "production site-water-sediment-soil-food-Residents" as basis for an in-situ treatment system in the craft-settlements of Nam Định province," Journal of Geology, vol. B/21, pp. 32-41, 2003.

[12] PPC of Thai Binh (Provincial people committee of Thai Binh), "Report on Environmental statement in Thai Binh province in the period 2011-2015", p. 170, Provincial people committee of Thai Binh, Thai Binh,Vietnam, 2015.

[13] T. L. Duong, T. H. Nguyen, T. D. Tran, T. A. Luu, T. H. T. Nguyen, and T. D. Pham, Project Report "Study on Heavy Metals Accumulation of $\mathrm{Hg}$, as and $\mathrm{Pb}$ and Some Pesticides in Surface Sediment and Ecological Risk for Serving Sustainable Developement of Aquculture in the Coastal Zone of Thai Binh Province, Institute of Geology, Vietnam Academy of Science and Technology, Hanoi, Vietnam, 2020.

[14] T. H. Bui, X. H. Nguyen, T. N. Nguyen, and T. H. Le, "Water quality of Ba Lat estuary," Vietnam Journal of Marine Science and Technology, vol. 20, no. 1, pp. 51-59, 2020.

[15] N. Hoai, T. Duc, H. Van et al., "Sedimentation rates and heavy metal concentrations in the tidal flats of North Vietnam," Polish Journal of Environmental Studies, vol. 28, no. 5, pp. 3721-3733, 2019.

[16] T. L. Duong, T. L. H. Nguyen, T. H. Nguyen et al., "Preliminary study of the distribution and risk assessment of mercury in different surficial sediments along the coastal area of the province Thai Binh in Vietnam," Environmental Pollutants and Bioavailability, vol. 32, no. 1, pp. 114-120, 2020.

[17] T. T. H. Nguyen, H. N. Vuong, W. G. Zhang et al., "Distribution of heavy metals in the topsoil of agricultural land in Nam Dinh province, Vietnam," Applied Ecology and Environmental Research, vol. 18, no. 5, pp. 6793-6811, 2020.

[18] H. D. Vu, "Control of environment in coastal zonce of Thai Binh province: present situation and solutions," Journal of Marine Natural Resources and Environment, vol. 2, pp. 13-16, 2015.

[19] D. T. Bui and V. D. Tran, "Status of hard clam farming in some coastal provinces of North and Northern central Vietnam," Journal of Science and Development, vol. 11, no. 7, pp. 972-980, 2013.

[20] T. H. Dang, N. D. Le, D. T. Vu, T. P. Q. Le, and T. T. Duong, "Assessment of water quality in coastal zone of the Red River in Nam Dinh province," in APAC: International Conference on Asian and Pacific Coasts, T. V. Nguyen, X. Dou, and T. T. Tran, Eds., pp. 837-843, Springer Nature Singapore Pte Ltd., Berlin, Germany, 2020.

[21] T. N. Duong, T. T. Cao, V. N. Le et al., Annual Project Reports "Monitoring and Analyzing Water Quality in Coastal Zone in the North Vietnam" During the Period 2016-2019, Institute of Marine Environment and Natural Resources, Vietnam Academy of Science and Technology, Hanoi, Vietnam, 2016-2019.

[22] AOAC International, Manual on Policies and Procedure (1998), AOAC International, Rockville, MD, USA, 2016.

[23] Addinsoft, XLSTAT Statistical and Data Analysis Solution, Addinsoft, Boston, MA, USA, 2019. 
[24] T. P.-Y. Chang and C. Rangan, "Iron poisoning: a literature-based review of epidemiology, diagnosis, and management," Pediatric Emergency Care, vol. 27, no. 10, pp. 978-985, 2011.

[25] P. J. Aggett, "Iron," in Present Knowledge in Nutrition, J. W. Erdman, I. A. Macdonald, and S. H. Zeisel, Eds., pp. 506-520, John Wiley \& Sons, Oxford, UK, 2012.

[26] FAO/WHO, "Evaluation of certain food additives and the contaminants mercury lead and cadmium," Technical report series 505, WHO, Geneva, Switzerland, 1989.

[27] EU, "Maximum levels for certain contaminants in foodstuffs," Official Journal of the European Union, vol. 364/5, 2006.

[28] J. L. Aschner and M. Aschner, "Nutritional aspects of manganese homeostasis," Molecular Aspects of Medicine, vol. 26, no. 4-5, pp. 353-362, 2005.

[29] D. S. Avila, R. L. Puntel, and M. Aschner, "Manganese in health and disease," Metal Ions in Life Sciences, vol. 13, pp. 199-227, 2013.

[30] A. Ikem and N. O. Egiebor, "Assessment of trace elements in canned fishes (mackerel, tuna, salmon, sardines and herrings) marketed in Georgia and Alabama (United States of America)," Journal of Food Composition and Analysis, vol. 18, no. 8, pp. 771-787, 2005.

[31] M. Gray, A. Harris, and J. A. Centeno, "The role of cadmium, zinc, and selenium in prostate disease," in Metal Contaminants in New Zealand: Sources, Treatments, and Effects on Ecology and Human Health, T. A. Moore, A. Black, J. A. Centeno, J. S. Harding, and D. A. Trumm, Eds., pp. 393-414, Resolutionz Press, Christchurch, New Zealand, 2005.

[32] IOM (Institute of Medicine), Dietary Reference Intakes for Vitamin A, Vitamin K, Arsenic, Boron, Chromium, Copper, Iodine, Iron, Manganese, Molybdenum, Nickel, Silicon, Vanadium, and Zinc, National Academies Press, Washington, DC, USA, 2001.

[33] MOFL (Ministry of Fisheries and Livestock Government of the People's Republic of Bangladesh). Bangladesh Gazette, Bangladesh Ministry of Fisheries and Livestock, SRO no.233/ Ayen, 2014.

[34] "CEC (commission of the European communities)," Commission Regulation (EC) No. 466/2001 of 8 March 2001 Setting Maximum Levels for Certain Contaminants in Foodstuffs, Official Journal of the European Communities, European Union, 2001.

[35] N. T. Luu and C. T. Nguyen, "A preliminary study of cadmium accumulation on noble scallop (Mimachlamys Nobilis) and undulating venus (Paphia Undulata) under experimental conditions," Journal of Aquacultural Sciences and Technology, vol. 1, pp. 60-67, 2017.

[36] G. Shirneshan, A. Riyahi Bakhtiari, S. J. Seyfabadi, and S. Mortazavi, "Significant correlation of $\mathrm{Cd}, \mathrm{Cu}, \mathrm{Pb}$ and $\mathrm{Zn}$ in sediments and oysters (Saccostrea cucullata) collected from Qeshm Island, Persian Gulf, Iran," Chemical Speciation \& Bioavailability, vol. 25, no. 4, pp. 291-302, 2013.

[37] V. M. Vo, V. K. Nguyen, T. K. Kieu, and T. A. Vu, "Contents of $\mathrm{Cd}, \mathrm{Pb}, \mathrm{Cr}$ and $\mathrm{Hg}$ in sediments and the clam Corbicula subsulcata from some estuaries of central Vietnam," Journal of Biology, vol. 36, no. 3, pp. 378-384, 2015.

[38] M. A. E. Gammal, A. Almadan, and N. Fita, "Shrimp, crabs and squids as bio-indicators for heavy metals in Arabian Gulf, Saudi Arabia," International Journal of Fisheries and Aquatic Studies, vol. 4, no. 6, pp. 200-207, 2016.

[39] G. M. Mbeh, F. T. Kamga, A. K. Kengap, W. E. Atem, and L. O. Mbeng, "Quantification of heavy metals (Cd, Pb, Fe, Mg, $\mathrm{Cu}$, and $\mathrm{Zn}$ ) in seafood (fishes and crabs) and evaluation of health risks to consumers in Limbe, Cameroon," Journal of Materials and Environmental Sciences, vol. 10, no. 10, pp. 948-957, 2019.

[40] B. Kumar, K. S. Sajwan, and D. Mukherjee, "Distribution of heavy metals in valuable coastal fishes from North East Coast of India," Turkish Journal of Fisheries and Aquatic Sciences, vol. 12, pp. 81-88, 2012.

[41] H. Ahdy, A. Abdallah, and F. Tayel, "Assessment of heavy metals and nonessential content of some edible and soft tissues," Egyptian Journal of Aquatic Research, vol. 33, no. 1, pp. 85-97, 2007.

[42] T. A. M. Tran, M. Leermakers, T. L. Hoang, V. H. Nguyen, and M. Elskens, "Metals and arsenic in sediment and fish from Cau Hai lagoon in Vietnam: ecological and human health risks," Chemosphere, vol. 210, pp. 175-182, 2018.

[43] A. S. Shafiuddin Ahmed, S. Sultana, A. Habib et al., "Bioaccumulation of heavy metals in some commercially important fishes from a tropical river estuary suggests higher potential health risk in children than adults," PLoS One, vol. 14, no. 10, Article ID e0219336, 2019.

[44] Q. Ahmed and L. Bat, "Mercury ( $\mathrm{Hg}$ ) levels in Indian mackerel Rastrelliger kanagurta (Scombridae) from karachi fish harbour and its risk assessment," Journal of Fisheries Sciences, vol. 9, no. 3, pp. 356-360, 2015.

[45] M. W. Ashraf and A. Mian, "Levels of mercury and arsenic contamination in popular fish and shrimp brands consumed in Saudi Arabia," Bulletin of the Chemical Society of Ethiopia, vol. 33, no. 3, pp. 573-578, 2019.

[46] U. Omuvwie and O. E. Atobatele, "Growth pattern, condition factor, trace metal studies and ectoparasitic load of the blue crab, Callinectes amnicola from Lagos Lagoon, Badore, Ajah, Lagos, Nigeria," Cameroon Journal of Experimental Biology, vol. 9, no. 1, pp. 34-43, 2013.

[47] A. Soegianto, B. Irawan, and Hamami, "Bioaccumulation of heavy metals in aquatic animals collected from coastal waters of Gresik, Indonesia," Coastal Environments: Focus on Asian Regions, vol. 9789048130, no. 2014, pp. 144-154, 2012.

[48] A. Soegianto, N. Moehammadi, B. Irawan, M. Affandi, and Hamami, "Mercury concentrations in edible species harvested from Gresik coast, Indonesia and its health risk assessment," Cahiers de Biologie Marine, vol. 51, no. 1, pp. 1-8, 2010.

[49] A. Bintal, "Concentration of heavy metals in molluscs and sediment from Sei Jang estuary," ILMU KELAUTAN: Indonesian Journal of Marine Sciences, vol. 9, no. 1, pp. 31-36, 2004.

[50] F. Budiyanto, U. Y. Arbi, and Suratno, "Risk assessment on mercury concentration in six edible mollusks from Bintan Island, Indonesia," in Proceedings of the International Conference on Biology and Applied Science (ICOBAS), Malang, Indonesia, July 2019.

[51] M. Meng, J.-b. Shi, C.-b. Liu et al., "Biomagnification of mercury in mollusks from coastal areas of the Chinese Bohai Sea," RSC Advances, vol. 5, no. 50, pp. 40036-40045, 2015.

[52] L. N. Liang, "Evaluation of mollusks as biomonitors to investigate heavy metal contaminations along the Chinese Bohai Sea," The Science of the Total Environment, vol. 324, no. 2004, pp. 105-113, 2003.

[53] N. A. M. Yusoff and S. M. Long, "Comparative bioaccumulation of heavy metals ( $\mathrm{Fe}, \mathrm{Zn}, \mathrm{Cu}, \mathrm{Cd}, \mathrm{Cr}, \mathrm{Pb}$ ) in different edible mollusk collected from the Estuary Area of Sarawak River," in Proceedings of the Universiti Malaysia Terengganu 10th International Annual Symposium, Malaysia, pp. 806-811, Malaysia, 2011.

[54] Q. H. Phan, "Assessment of heavy metal concentrations in industrial activities in agricultural land in Thai Binh 
province," Journal of Agriculture \& Rural Development, vol. 16, pp. 21-30, 2017.

[55] V. T. Nguyen, Y. Osanai, T. Adachi et al., "Chemical speciation and bioavailability concentration of arsenic and heavy metals in sediment and soil cores in estuarine ecosystem, Vietnam," Microchemical Journal, vol. 139, pp. 268-277, 2018.

[56] F. Guerra, A. R. Trevizam, T. Muraoka, N. C. Marcante, and S. G. Canniatti-Brazaca, "Heavy metals in vegetables and potential risk for human health," Scientia Agricola, vol. 69, no. 1, pp. 54-60, 2012.

[57] S. Wang, W. Wu, and F. Liu, "Assessment of the human health risks of heavy metals in nine typical areas," Environmental Science and Pollution Research, vol. 26, no. 12, pp. 12311-12323, 2019.

[58] A. Sharma, J. K. Katnoria, and A. K. Nagpal, "Heavy metals in vegetables: screening health risks involved in cultivation along wastewater drain and irrigating with wastewater," SpringerPlus, vol. 5, no. 1, p. 488, 2016. 